УДК 340.132 .6

DOI https://doi.org/10.32837/yuv.v0i5.2241

\author{
У. Гришко, \\ кандидат юридичних наук, \\ викладач кафедри цивільного права \\ Навчально-наукового юридичного інституту \\ Прикарпатського національного університету \\ імені Василя Стефаника
}

\title{
ТЕОРЕТИКО-МЕТОДОЛОГІЧНІ ПІДСТАВИ ДОГОВІРНОГО ПРАВОВОГО РЕГУЛЮВАННЯ
}

\section{Постановка}

Основним завданням права $€$ регулювання суспільних відносин. Безумовно, воно виступає не єдиним, але найбільш ефективним та універсальним регулятором соціальної реальності. Особливості функціонування механізму та апарату державної влади, взаємодії публічної влади та громадянського суспільства, відкритості рішень правового характеру - все це безпосередньо впливає на ефективність правового регулювання, його соціально-гуманістичний вимір.

Ключовою родовою інтенцією правового регулювання $€$ соціальне регулювання, оскільки в широкому розумінні суспільство віддає державі частину своєї свободи заради консенсусного співіснування всіх елементів соціальної системи. Правове регулювання сприяє формуванню та оцінюванню поведінки особи відповідно до єдиних критеріїв виміру, сприяє унормуванню зворотної реакції на поведінкові прояви, уніфікує стандарти та правила комунікаційних відносин. Ця діяльність сприяє утвердженню сталості людських відносин відповідно до історично вироблених принципів та погоджених правил.

Заради належного унормування правовідносин теоретична юриспруденція та юридична практика розробили різного характеру механізми, використання яких призводить до отримання позитивного соціального результату. Правове регулювання усуває соціальні потрясіння, колізійні дисонанси та є чітким й однозначним, організованим та потенційно результативним. У державі соціальної демократії важливо дотримуватися меж регламентації правових відносин, оскільки надмірне імперативне регулювання у виключно дозвільному характері зумовлює надмірну регламентацію суспільних відносин, спричиняє фінансово-економічний спад та культурну девіацію.

У більшості випадків порядок регулювання має дозвільну форму, тобто від імені держави органи публічної влади закріплюють умови, порядок та норми правової поведінки. Проте в умовах демократичної державної ідеології всі відносини не можуть регулюватися виключно велінням правотворчого суб'єкта. Тенденції розвитку суспільних відносин, що грунтуються на доктрині верховенства права, людиноцентризму і гуманізму, уособлюють потребу своєчасного та якісного правового регулювання, яке б установлювало можливу варіативну поведінку суб'єктів права.

Вказане актуалізує проблематику договірного правового регулювання щодо визначення його правової природи, ознак, переваг і тенденцій прояву. Не може залишатися осторонь і зміна методологічного інструментарію теоретичного тлумачення усталених категорій у вимірі глобальних транзитивних трансформацій. 
Аналіз наукових публікацій. $\mathrm{y}$ національній доктрині до питання правового регулювання зверталися такі науковці, як С. Бостан, Н. Оніщенко, Л. Лепех, О. Мельник, О. Куракін та ін., щодо оновлення методологічного інструментарію правознавства цінними $є$ доробки M. Кельмана, Ю. Бисаги, І. Жаровської, О. Петришина, С. Бобровник. Загалом, теорія держави і права досить давно сформувала погоджену парадигму дефініціювання поняття правового регулювання, виокремила його види, методи. Класичним є усталений поділ на імперативний та диспозитивний методи правового регулювання. Тому сучасні наукові праці недостатньо звертають увагу на досліджувану проблематику, вважаючи вказане питання погодженим або ж, навпаки, віддаючи перевагу галузевому аналізу, зазвичай на рівні цивільно-правової науки.

Варто звернути увагу, що проблематика теоретичного розуміння договірного правового регулювання в іноземній науковій літературі розкрита також не повною мірою. Акцент науковцями проводиться на відмінностях приватного та публічного права в договірному регулюванні (Hanoch Dagan, Avihay Dorfman) [1], проведенні різниці між абсолютними та відносними правами та абсолютизації права щодо сутності обіцяного виконання (Jan Felix Hoffmann) [2], проблемі уніфікації праворегулятивної договірної форми (Andrew Jordan) [3]. Науковці звертають увагу, що сьогодні відбувається актуалізація договірних відносин у контексті глобальних загроз пандемічного характеру (Ch. Bauer, M.B. Fandinj) [4], фахівці вказують на те, що пандемія підтверджує роль договірного права як надзвичайного права, та закликають уряди зміцнити свободу укладання угод та розширити сферу договірного регулювання (Xuan-Thao Nguyen) [5].

Також здебільшого проблеми договірного регулювання висвітлюється в контексті системи законо- давства окремої території, наприклад Південної Африки (Louis F. van Huyssteen, Catherine J. Maxwell) [6], Індонезії (S. Irianto) [7], Польщі (P. Machnikowski, J. Balcarczyk, M. Drela) [8].

Фактично єдину спробу методологічного обгрунтування договірного регулювання в іноземній літературі останніх років зроблено ізраїльським науковцем О. Катцом (Ori Katz) [9] шляхом репрезентування його через ідеологічне різноманіття щодо договірного права з використанням чотирьох ключових колізій: індивідуалізм проти солідарності; формалізм проти антиформалізму; егалітаризм проти неегалітаризму; інструментальні / економічні та внутрішні перспективи.

Вказане зумовлює потребу констатувати факт відсутності предметного наукового аналізу теоретичних та методологічних підстав договірного правового регулювання, що й підтверджує потребу подолання такої доктринальної потреби в межах цієї наукової статті.

Метою статті $€$ аналіз теоретичних та методологічних аспектів підстав договірного правового регулювання в сучасному глобалізованому та транзитивному суспільстві.

Виклад основних положень. Правове регулювання можна охарактеризувати як «особливий формалізований метод державної регламентації дій суб'єктів права з метою спрямування їхньої поведінки відповідно до інтересів громадян, суспільства і держави, воно потребує, на думку Н. Оніщенко, комплексного вивчення відповідних складників у їхній нерозривній взаємодії, тобто як цілісної системи, яка складається 3 певних ланок, що знаходяться у взаємодії, та кожна з них випливає 3 попередньої» [10, с. 48]. Ці ланки включають дозвільні та договірні засоби впливу. Саме через них і виводить дефініцію «правове регулювання» у своїй дисертації Л. Лепех, указавши, що воно «є спеціально-юридичним впли- 


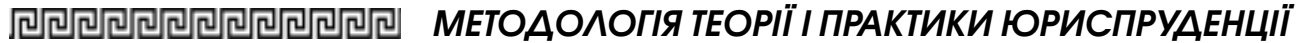

вом, однією з форм реалізації функцій права, здійснюваної за допомогою спеціальних правових засобів» [11, с. 68].

У демократичному суспільстві категорія «регулювання» не $є$ тотожною примусу, жорсткому і владному припису. Норма права встановлює лише модель відносин, в якій суспільні інтереси мають співвідноситися з інтересами членів суспільства, поряд із цим право широко використовує такі засоби впливу на поведінку людей, як стимулювання, заохочення, надання прав тощо [12, с. 29].

Контент-аналіз чинного законодавства різногалузевого законодавства дає можливість мотивувати затребуваність договірних конструкцій, котрі залучені до регулювання відносин. Загалом, сучасна практика свідчить про відсутність погодженої концепції договорів, що вказує на можливі прогалини в регулюванні та породжує проблеми праксіологічного характеру. Договір виступає самостійним джерелом права, окремим юридичним інструментом, що встановлює, змінює чи припиняє відносини та визначає індивідуальну волю суб'єктів права. Договірне регулювання встановлює права та обов'язки учасників і є засобом узгодження законних інтересів сторін, їхніх прагнень та тенденцій розвитку предмету співпраці. Державні інституції, впроваджуючи договірне правове регулювання суспільних відносин, надають певну міру свободи суб'єктам права і ставлять за мету запровадження більш гнучкого механізму регулювання цих відносин.

Договірне правове регулювання $€$ видом правової діяльності суб'єктів права, що носить організаційно-розпорядчий характер виключно для цих осіб та спрямоване на забезпечення безпеки суспільних відносин, концептуально сприяє впорядкуванню процесів, які формуються в соціумі, підтверджує легальність дій конкретних суб'єктів, може позначати як матері- альні, так і процесуальні чинники регламентації суспільних відносин.

Важливою підставою впровадження договірного правового регулювання $€$ узгодження його меж із державно-дозвільними режимами.

Аспекти співвідношення можуть бути різними, наприклад, це паралельне та одноосібне функціонування одного з видів регулювання. Перше характеризується функціонуванням двох методів, при цьому з чіткими характеристики меж і сфери суспільних відносин, на які вони поширюються. О.М. Кривов'яз шодо цього акцентує, що «неможливо врахувати всі нюанси регулювання тих чи інших суспільних відносин, завжди знайдеться якась прогалина, яка викличе проблему в здійсненні реалізації того чи іншого права, а правочин у такому випадку стане особливим регулятором, який створить нову норму задля врегулювання тієї чи іншої ситуації» [14, с. 71].

Не можна допускати колізійності регулювання. Професор Т. Харитонова надає такий приклад. Вона вбачає колізію у визначенні строку договору між Цивільним Кодексом України та Законом України «Про внесення змін до деяких законодавчих актів України щодо вирішення питання колективної власності на землю, вдосконалення правил землекористування в масивах земель сільськогосподарського призначення, запобігання рейдерству та стимулювання зрошення в Україні» № 2498VIII від 10.07.2018 р., яким було внесено зміни до ст. 1021 ЗК щодо строку емфітевзису. Тепер строк користування земельною ділянкою державної, комунальної та приватної власності став однаковим для всіх суб'єктів і становить 50 років. Але якщо звернутися до ст. 408 ЦК, яка також містить норму щодо строку договору емфітевзису, то п. 1 вищезазначеної статті залишився без змін, залишаючи обмеження щодо строку користування у 50 років лише для 
земельних ділянок державної або комунальної власності. Науковиця констатує, що «була створена колізія між двома кодексами, що призводить до значної кількості судових спорів, оскільки під час укладання договорів насамперед ураховуються норми ЦК» [13, с. 241].

Одноосібність договірного регулювання відбувається зазвичай у тих відносинах, де за різними підставами нормативно-правове регулювання не відбувається. Здебільшого йдеться про новітні правовідносини, де відсутні усталені правові стандарти. Розвиток науки, медицини, біології, техніки спровокував появу відносин, які мають інтенсивний характер, та спричинив прогалини регулювання. Договірне регулювання може інтенсивно подолати вказану проблему в найкоротший час порівняно з іншими джерелами права.

Знову-таки звернемося до практики. В Україні відсутнє спеціалізоване нормативно-правове законодавче регулювання сурогатного материнства як процедури реалізації права на продовження роду. Відповідно до положень Порядку застосування допоміжних репродуктивних технологій в Україні, серед необхідних для проведення сурогатного материнства документів 3 боку подружжя подається нотаріально засвідчена копія письмового спільного договору між сурогатною матір'ю та жінкою (чоловіком) або подружжям [15]. Отже, правова політика держави прямо вказує на те, що відносини в репрезентованій сфері необхідно регулювати в договірному порядку.

Вищевказане зумовлює потребу виокремлення теоретичних підстав договірного правового регулювання в сучасних умовах розвитку суспільства. Виділимо такі з них.

По-перше, договірне регулювання потребує двостороннього/ багатостороннього волевиявлення суб'єктів правовідносин. На відміну від інших джерел права, як, наприклад, норма- тивний акт, правовий звичай чи правовий прецедент, договір має унікальний характер, тому що не може бути одностороннім вольовим рішенням, це завжди дво- чи багатосторонній акт.

По-друге, договірне регулювання у своїй антропологічній природі містить консенсус договірних сторін. Тут має бути присутня узгодженість, інтегрування, взаємодія волі сторін договору. Домінантною правовою ідеологією для договірної сфери $€$ консенсусність (згода). Вказане неможливо без досягнення правового компромісу. Як вказує С. Бобровник, «він $є$ однією $з$ визначальних засад функціонування демократичного режиму, основою легітимації влади, яка є суб'єктом закріплення та гарантування прав людини. Це ефективний засіб упорядкування правових конфліктів у сфері прав людини; правовий компроміс викликає юридичні наслідки для суб'єктів суспільних відносин, у тому числі шляхом застосування примусових засобів до суб'єктів, які не виконують обов'язків чи порушують права інших суб'єктів. Нарешті, правовий компроміс є умовою будь-яких правовідносин у сфері реалізації прав людини. Саме досягнення правового компромісу у сфері прав людини забезпечує можливість вирішення конфліктів та визначає рівень ефективності діяльності держави в означеній сфері» [16, с. 45].

По-третє, підставою належного регулювання буде імплементування в договірних відносинах особистої волі сторін. Науковці вказують, що договір має регулятивний характер і значення як правового інструменту, засобу, «виходячи 3 потреби забезпечення своїх інтересів, за власною волею, вступають у відносини та визначають у них конкретний зміст, деталізують права та обов'язки, тим самим забезпечуючи регулювання своїх відносин» [17, c. 253].

Мінімізація примусу в реалізації суспільних відносин є визначною характеристикою демократичного 


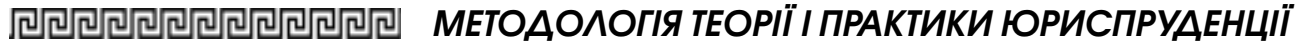

транзитивного суспільства та правової держави, оскільки тоді механізм правового регулювання діє природно і синхронно, грунтуючись на потребі учасників суспільного процесу, тому немає потреби застосовувати примусові важелі впливу. Вони можуть залишатися превентивними складниками унормування, але в договірному порядку виконання відбувається добровільно, спираючись на належний рівень правової соціалізації та правосвідомості учасників юридичної діяльності. Така характеристика за нормативного регулювання, здавалось би, має утопічне забарвлення. Однак вона цілком прийнятна для договірних відносин, де виконання мало б носити добровільний характер, оскільки виникло з особистої свобідної волі суб'єкта права, а не нав'язано державою чи іiі інституціями.

Четвертою підставою договірного регулювання буде те, що воно націлено на досягнення корисного соціального результату. Як свідчить юридична практика, право нормотворця не повністю відповідає соціальним потребам і своєчасно їх відображає. «За найпромовистіший приклад можна взяти радянські законодавчі акти, спрямовані на примусову колективізацію сільського господарства, націоналізацію промисловості й землі. Цілі цих законодавчих актів досягнуті, але чи можна оцінювати проведені заходи як соціально ефективні? Безумовно, в процесі правового регулювання мають спростовувати хибну думку про те, що мета виправдовує засоби. Застосування антигуманних правових засобів, завуальованих під суспільно корисні, зрештою, спричиняє те, що їх не підтримує значна частина населення» $[17$, с. 70$]$.

По-п'яте, потреба в договірному регулюванні виникає лише в разі можливості врегулювання відносин за допомогою індивідуальної норми. Особливість у тому, що така норма не може суперечити загальним правовим нормам і принципам визначеної юри- дичної ідеології держави. «Першим і головним елементом виключного значення механізму правового регулювання договірних відносин $€$ саме нормативна основа (норма права як юридичний факт, що визначає поведінковий аспект договірного правовідношення. Такими нормами $€$ норми статутного цивільного права (встановлені державою) та (або) створювані самими учасниками цивільних відносин норми договірного цивільного права» [18, с. 241-242].

Також окремого предметного аналізу потребує методологічна парадигма договірних відносин.

Основою сучасного методологіювання в репрезентованій сфері аналізу має стати поєднання підходів узгодженості приватного та публічного регулювання.

Теорії публічного регулювання ототожнюють саме поняття регулювання з нормативним примусом, указують на імперативність та безальтернативність вибору в разі державного унормування, яке є домінуючим для суспільних норм.

Теорії приватного регулювання здобули особливий розвиток під впливом політичної ідеології дерегулювання. Ця група теорій підкреслює небезпечність «регуляторної неспроможності» i «регуляторної сліпоти» теорій, орієнтованих на публічний інтерес. Адже поза увагою таких «публічних» теорій залишаються численні індивідуальні інтереси, які потребують інших підходів у регулюванні [19, с. 34].

Поєднання індивідуального (договірного) та публічно-правового критерію під час формування суспільних відносин передбачає необхідність розумного пропорційного вибору у визначенні закономірних засобів i механізмів юридично регламентованої та дозволеної поведінки, поєднання казуального і нормативного порядку (на основі норм права в поєднанні з індивідуальними договорами).

Синергетичне методологічне niдsрунтя вимагає оновленого 
розуміння всіх правових явищ у глобальному суспільстві. «У зв'язку з цим цілком очевидним висновком варто визнати, що сучасне право в демократичній державі вже не лише безпосередньо регулює ті чи інші суспільні відносини, закріплюючи в нормах конкретні моделі поведінки, права i обов'язки їхніх учасників тощо, а й впливає на їх подальший розвиток, до певної міри визначає тенденції їх еволюції в майбутньому, забезпечуючи тим самим інтереси суб'єктів права та можливість передбачення ними перспектив своєї подальшої діяльності» [10, с. 47]. Усталені інститути (договірне регулювання в тому числі) також змінюють свої прояви. Особливістю проявів у транзитивній реальності $€$ те, що, перебуваючи в «точці біфуркації, неможливо передбачити вектор розвитку правового регулювання. Дослідники, нормотворці, праворегулятори не можуть ствердно передбачити, які зовнішні чи внутрішні атрактори спричинять трансформацію договірного регулювання. Тому саме синергетична методологія сприяє виокремленню транзитивних підстав договірного регулювання.

Серед останніх тенденцій ми виокремимо появу нових форм договірних відносин, наприклад, договори, укладені в електронній формі. Як мотивує С. Пилипенко, «в умовах сьогодення йдеться не лише про розширення сфер діяльності за участі суб'єктів цивільно-правових відносин, а і про необхідність їх правового регулювання з урахуванням сучасних економічних тенденцій та новітніх технологічних досягнень. Мобільність договору, що виражається у спрощенні процедури його укладення, та можливість обміну інформацією за допомогою електронних засобів зв'язку $є$ тими напрямами, які сприяють удосконаленню правового регулювання договірних відносин» [20, с. 49]. Змінюється не тільки форма, але й сфера договірного регулювання, оскільки «натепер немає єдиного підходу до вибору оптимальної форми правового регулювання інтелектуальних контрактів у системі договірного права в сучасних правових системах або міжнародному праві, тоді як глобалізація та цифровізація економіки передбачають зростання транскордонних операцій. Поява розумних контрактів пояснюється розвитком електронної комерції, в якій взаємодія сторін здійснюється в електронному вигляді замість фізичних обмінів або безпосереднього фізичного контакту» [21].

Розширювальний підхід у договірному регулюванні також знаходить своє методологічне обгрунтування. Як визначає в дисертації С. Панченко, «інтеграційні процеси, що відбуваються у світі, істотно впливають на правові системи держав-учасників i, як наслідок, зумовлюють необхідність переусвідомлення позицій щодо джерел права та пошуку оптимальних моделей гармонізації правового регулювання суспільних відносин у контексті інтеграційних змін» [22, с. 18]. Сьогодні договірне регулювання отримує значну сферу застосування, має універсальний характер. У попередній правовій ідеології, враховуючи чіткий галузевий та інституційний поділ, договірне регулювання було притаманне цивільно-правовим відносинам (приватно-правовим), і лише в їхніх межах завершувалось його застосування. Користуючись науковими надбаннями римського та цивільного права, парадигми договірного регулювання треба імплементувати в інші галузі, навіть, здавалося б, такі, що мають абсолютний державно-управлінський характер. У цих сферах вони наділені можливістю пом'якшити імперативну модель відносин, зумовлюють децентралізацію владних повноважень, вносять механізми самоврядування та саморегуляції у владні відносини.

Переваги застосування розширеної сфери договірного регулювання продемонструємо на прикладі медіаційного договору. Так Н. Грень ука- 
зує, що, «окрім приватноправових, ефективність медіації з часом поширюється на інші види спорів, зокрема спорів публічного характеру. Прикладом можуть бути адміністративні спори: щодо оскарження рішень, дій чи бездіяльності органів влади; з приводу прийняття громадян на публічну службу, іï проходження, звільнення з публічної служби; спорів, що виникають із приводу укладання, виконання, припинення, скасування чи визнання нечинними адміністративних договорів; щодо правовідносин, пов'язаних 3 виборчим процесом чи процесом референдуму. Отже, одним 3 учасників виступає орган державної влади, через своїх представників вони використовують процедуру медіації для врегулювання конфлікту. Вказане не тільки підвищує довіру до судової влади, але й забезпечує демократизацію державної влади загалом, передбачає налагодження діалогу між громадянами і державою» [23, с. 108].

Розширення договірного регулювання зумовлено не лише проникненням договірного права в публічно-правові сфери, але й трансформацією всієї правової політики в бік гуманізації права, лібералізації правових відносин, демократизму та ціннісного виміру прав людини. Однак все ж необхідно зазначити, що інтенсифікація договірного права в різних галузях все ж залишається неоднаковою. Апарат публічного управління за допомогою системи договірних відносин визначає розвиток приватного, змішаного та державного секторів економіки й управляє суспільними процесами, залишаючи за собою в управлінських відносинах домінуючу роль дозвільних засобів.

Існує правова позиція науковців, що таке розширення сфери застосування договірного регулювання безпосередньо шкодить йому, деформуючи його правову природу. Р.Б. Шишка, вказуючи на використання переваг договірного регулювання суспільних відносин різними галузями права, всу- переч навіть визначальним положенням про метод правового регулювання гостро критикує таке використання договірних конструкцій та привнесення методів регулювання галузевих правовідносин у договірне право, що, на його думку, «засмічує договірне право, розмиває його сенс чи раціональне зерно, завдяки якому воно стало універсальним для узгодження різних, але близьких інтересів сторін договору» [24, с. 80]. Однак ми не можемо погодитися 3 цією позицією, оскільки в пріоритет, на нашу думку, потрібно ставити не чистоту договірного регулювання, а його ефективність. Норми права різного галузевого спрямування отримують за рахунок договірного регулювання додатковий засіб для розкриття свого потенціалу, кращого забезпечення прав та свобод громадян, досягнення аксіологічно погодженої соціальної цілі та пріоритету. Договірні відносини сприяють відкритості системи права, допомагають процесу спеціалізації права. Гнучкість договірної форми регулювання дає можливість урахувати різноманітні конкретні умови, обставини, фактори, особливості сфери життедіяльності. Затребуваність договірного регулювання продемонструємо статистикою, що вказує на активізацію уваги громадськості до можливого індивідуального унормування. За даними Міністерства Юстиції України у 2018-му році співвідношення кількості зареєстрованих шлюбів до кількості шлюбних контрактів становило $2,68 \%$, то у 2020 році цей показник збільшився до 4,44\% [25].

Висновки. Сучасне транзитивне суспільство вимагає оновлення теоретико-правового та методологічного аналізу договірного правового регулювання.

Отже, теоретичними підставами договірного правового регулювання $€$ : двостороннє / багатостороннє волевиявлення суб'єктів правовідносин; має містити унормований консенсус договірних сторін; імплементування 
в договірних відносинах особистої волі сторін; націлення на нього досягає корисного соціального результату; можливість урегулювання відносин за допомогою індивідуальної норми.

Основою сучасного методологіювання в репрезентованій сфері аналізу має стати: поєднання підходів узгодженості приватного та публічного регулювання, що передбачає поєднання індивідуального (договірного) та публічно-правового критерію у формуванні суспільних відносин; синергетичний підхід, що сприяє виокремленню транзитивних підстав договірного регулювання; розширювальний підхід, що відображає експансію договірного регулювання шляхом проникнення договірного права в публічно-правові сфери.

У cmammi подано аналіз теоретичних та методологічних аспектів підстав договірного правового регулювання в сучасному глобалізованому та транзитивному суспільстві.

Проведений контент-аналіз чинного законодавства різногалузевого законодавства дає можливість мотивувати затребуваність договірних конструкцій, котрі залучені до регулювання відносин. Загалом, сучасна практика свідчить про відсутність погодженої концепциї договірного регулювання, що вказуе на можливі прогалини в регулюванні та породжує проблеми праксіологічного характеру.

Вказано, шо важливою підставою впровадження договірного правового регулювання є узгодження його меж з державно-дозвільними режимами. Аспекти співвідношення можуть бути різними: паралельне та одноосібне функиіонування одного з видів регулювання. Доведено, що не можна допускати колізійності регулювання.

Виокремлено теоретичні підстави договірного правового регулювання в сучасних умовах роз- витку суспільства, а саме: потреба двостороннього / багатостороннього волевиявлення суб'єктів правовідносин; має містити унормований консенсус договірних сторін; імплементування в договірних відносинах особистої волі сторін; націлення досягае корисного соціального результату; можливість урегулювання відносин за допомогою індивідуальної норми.

Авторами вмотивовано, щзо основою сучасного методологіювання в репрезентованій сфері аналізу має стати: поєднання підходів узгодженості приватного та публічного регулювання, що передбачае поеднання індивідуального (договірного) та публічно-правового критерію у формуванні суспільних відносин, відображае необхідність розумного пропориійного вибору у визначенні закономірних засобів $i$ механізмів юридично регламентованої та дозволеної поведінки; синергетичний підхід, щзо є корисним під час дослідження оновленого розуміння всіх правових явищ у глобальному суспільстві та сприяе виокремленню транзитивних підстав договірного регулювання; розширювальний підхід, що відображае експансію договірного регулювання шляхом проникнення договірного права в публічно-правові сфери $i$ трансформацію всієі правової політики в бік гуманізації права, лібералізації правових відносин, демократизму та ціннісного виміру прав людини.

Ключові слова: правове регулювання, договірне правове регулювання, методологія, приватно-правові відносини, публічно-правові відносини, підстави.

\section{Hryshko U. Theoretical and methodological basis contractual legal regulation}

The article presents an analysis of theoretical and methodological aspects of the basis of contractual 
legal regulation in a modern globalized and transitive society.

The conducted content analysis of the current legislation of various sectoral legislation provides an opportunity to motivate the demand for contractual structures involved in the regulation of relations. In general, modern practice shows the lack of an agreed concept of agreements, which indicates possible gaps in regulation and creates problems of a praxiological nature.

It is indicated that an important basis for the introduction of contractual legal regulation is the harmonization of its boundaries with state licensing regimes. Aspects of the relationship can be different: parallel and individual operation of one of the types of regulation. It is proved that collision regulation cannot be allowed.

The theoretical bases of contractual legal regulation in modern conditions of society development are singled out, namely: it requires bilateral / multilateral expression of will of subjects of legal relations; must contain a standardized consensus of the contracting parties; implementation of the personal will of the parties in contractual relations; targeting achieves a useful social result; the possibility of settling relations with the help of individual norms.

The authors are motivated that the basis of modern methodology in the represented field of analysis should be: a combination of approaches to the coherence of private and public regulation, which involves a combination of individual (contractual) and public law criteria in the formation of public relations, reflects the need for reasonable proportional choice legally regulated and permitted behavior; a synergetic approach, which is useful in the study of an updated understanding of all legal phenomena in global society and helps to identify the transitive basis of contractual regulation; an expanding approach that reflects the expansion of contractual regulation through the penetration of contract law into public law and administrative relations, the transformation of all legal policy towards the humanization of law, liberalization of legal relations, democracy and the human rights dimension.

Key words: legal regulation, contractual legal regulation, methodology, private-legal relations, public-legal relations, grounds.

\section{Література}

1. DaganH.,DorfmanA.JustRelationships. Colum. L. Rev. 2016. V. 116. P. 1395.

2. Hoffmann J.F. Contract Law Theory and The Concept of 'Ownership'. European Review of Contract Law. 2021. URL: https: / / doi.org / 10.1515/ ercl-2021-2021

3. Jordan A. Uniformity and Multiplicity in Contract Law: Some Reflections on the Morality of Promises (August 19,2021). URL: https: / / ssrn.com / abstract= 3908100 or http://dx.doi.org/10.2139/ ssrn.3908100

4. Bauer Ch., Fandinj M.B. Rev. Contractual Solidarism and Relational Contract Theory: Alternative Approaches to Contract Law in Light of the Covid19 Pandemic. Derecho Privado. 2021. V. 41. P. 53.

5. Nguyen $X$-Th. Contract as Emergency Law, Wash. L. Rev. 2021. V. 30. URL: https: / / digitalcommons.law.uw.edu / wilj / vol30 / iss3 / 9

6. Huyssteen van L., Maxwell C. Contract Law in South Africa. The Netherland: Wolters Kluwer Law \& Business. 2021. $203 p$.

7. Irianto S. Butterfly Effect in Development of Contract Law in Indonesia. Reviewof International Geographical Education (RIGEO). 2021. V. 11(5). P. 3365-3374.

8. Machnikowski P., Balcarczyk J., Drela M. Contract Law in Poland The Netherland: Wolters Kluwer Law \& Business. 2020. 98 p

9. Katz O. Mapping the Diversity of Thought-An Attitude Theory of Contract 


\section{ЮРИАИЧНИЙ ВІСНИК, 2021/5}

Law. Southern California Interdisciplinary Law Journal, Forthcoming. 2021. URL: https: / / ssrn.com / abstract $=3925338$

10. Онішенко Н.М. Правове регулювання, правовий вплив та правове забезпечення: індекс взаємовизначеності. Правова держава. 2020. Bun. 31. C. 46-53.

11. Лепех Л.Л. Соціальна та юридична ефективність механізму правового регулювання : дис. ... на здобуття наук. cтуп. канд. юрид. наук: 12.00.01. Київ: Науково-досліднии інститут публічного права, Національний університет «Львівська політехніка», 2019. 234 с.

12. Тарахонич T.I. Види правового регулювання: теоретичні аспекти розуміння. Часопис Київського університету права. 2014. № 4. С. 28-31.

13. Харитонова T.E. Зміни у законодавстві та нові колізії щодо емфітевзису. Правове життя сучасної України : у 3 m. : матеріали Міжнар. наук.-практ. конф. (м. Одеса, 15 трав. 2020 р.) / відn. ред. М.Р. Аракелян. Одеса : Гельветика, 2020. T. 2. C. 239-242.

14. Кривов'яз О.М. Правочин як джерело иивільного права. Часопис иивілістики. 2015. Bun. 18. C. 69-72.

15. Про затвердження Порядку застосування допоміжни репродуктивних технологій в Україні : Наказ МОЗ України від 09.09.2013 р. № 787. URL: https: / / zakon.rada.gov.ua/laws / show / z1697-13

16. Бобровник С.В. Доктринальний аналіз правового компромісу та його роль у забезпеченні прав людини. Альманах права. Роль правової доктрини у забезпеченні прав людини. Київ : Iнститут держави і права імені В.М. Корещького НАН України, 2020. Bun. 11. С. 42-47.

17. Гетьман А.П., Борисова В.I., Євсєєв О.П. Договір як універсальна правова конструкція : монографія. Харків : Право, 2012. $428 \mathrm{c}$.

18. Федик Є.I., Горецька Х.В. Механізм правового регулювання договірних відносин Сучасні напрями розвитку економіки, підприємництва, технологій ma їх правового забезпечення : мате- ріали Міжнародної науково-практичної конферениіі / відповід. за вип. : проф. Б.Б Семак. Львів : вид-во Львівського торговельно-економічного університету 2021. C. 241-242.

19. Мухін В.В. Індивідуальне правове регулювання в контексті теорій публічного $i$ приватного інтересу Науковий вісник Ужгородського національного університету. Серія : Право. 2018. Bun. 51(1). C. 33-35.

20. Пилипенко С. Особливості правового регулювання відносин за договором, укладеним в договірній формі. Підприємниитво, господарство $і$ право. 2020. Bun. 8. C. 48-53.

21. Sinitsyn S.A., Diakonova M.O., Chursina T.I. Smart Contracts in the Digital Economy: Contractual Regulation and Dispute Resolution. In: Inshakova A.O., Frolova E.E. (eds) Smart. Technologies for the Digitisation of Industry: Entrepreneurial Environment. Smart Innovation, Systems and Technologies. 2021. vol 254. Springer, Singapore. URL: https://doi.org/10.1007 /978-981-16-4621-8_13

22. Панченко С.В. Джерела иивільного договірного права: дис. ... на здоб. наук. ступ. доктора філософії : 081 «Право». Хмельницький : Хмельницький університет управління та права імені Леоніда Юзькова Хмельницької обласної ради, 2021.

23. Грень Н.М. Реалізація права на справедливий суд шляхом процедури присудової медіації: теоретико-правове дослідження : дис. ... на здоб. наук. ступ. канд. наук : 12.00.01. Львів : НУ «Львівська політехніка», 2016. $250 \mathrm{c}$.

24. Шишка Р.Б. Проблеми видів та характеристики иивільних та господарських договорів. Розробка механізму правового регулювання договірних відносин у підприємницькій діяльності : монографія / за ред. акад. АПрН України В.В. Луия. Київ : НДІ приватного права $і$ підприємництва, 2009.

25. Дані Міністерства Юстиції Украіни. URL: https: / /drive.google.com/ drive / u /0/folders / 1scFE4UQCYIsApv02 9XWzAd3_Nl14u5Rb 